\title{
THE MISSING LINK IN AUSTRALIAN TERTIARY EDUCATION: SHORT-CYCLE HIGHER EDUCATION
}

\begin{abstract}
The diploma and advanced diploma have long been contested territory in Australian sectoral turf wars. The current settlement allows vocational education and training and higher education to offer their own versions of diplomas and advanced diplomas. This and Australia's unusually deep organisational separation of vocational education and training and higher education has made it difficult for governments to adopt an integrated tertiary education policy and it has restricted vet's role. By comparing arrangements for the highest sub baccalaureate qualifications in North America and the UK, known generically as shortcycle higher education, the paper develops some new options for Australia. The paper concludes by arguing that Australia should follow the North America and UK examples and decouple the institutional and programmatic designations of the sectors to allow vet institutes to offer unambiguously higher education programs.
\end{abstract}

\section{INTRODUCTION: DIPLOMAS AND ADVANCED DIPLOMAS}

Sub baccalaureate diplomas and advanced diplomas are located ambiguously within Australian tertiary education. The Australian Qualifications Framework classifies these 
qualifications as both vocational education and training and higher education, depicting their relationship with other tertiary education qualifications thus.

TABLE 1: AQF’S DEPICTION OF TERTIARY EDUCATION QUALIFICATIONS

\begin{tabular}{|l|l|}
\hline Vocational education & Higher education \\
\hline & Doctorate \\
\hline & Masters \\
\hline & Graduate diploma \\
\hline & Graduate certificate \\
\hline Advanced diploma & Advanced diploma \\
\hline Diploma & Diploma \\
\hline Certificate IV & \\
\hline Certificate III & \\
\hline Certificate II & \\
\hline Certificate I & \\
\hline
\end{tabular}

Source: Australian Qualifications Framework 2002, table 1

In 2001 publicly funded vocational education and training had 18,520,000 annual hours at Australian Qualifications Framework advanced diploma level and it had 56,760,000 annual hours at AQF diploma level, totalling 75,280,000 annual hours (NCVER, 2001:22). Annual 
hours may be converted to equivalent fulltime students by dividing by 720 (Williams, 1979:55), giving 104,556 equivalent fulltime students at diploma and advanced diploma levels. This is almost 20\% of total publicly funded vet load. By contrast in 2001 there were only 6,391 equivalent full time student units enrolled in diploma and advanced diploma level courses in higher education institutions, which was only just over $1 \%$ of total load in higher education institutions (DEST, 2002: table 46).

TABLE 2: $\quad$ STUDENT LOAD IN DIPLOMAS AND ADVANCED DIPLOMAS AND AS A PROPORTION OF ALL LOAD IN VOCATIONAL EDUCATION AND TRAINING AND HIGHER EDUCATION INSTITUTIONS

\begin{tabular}{|l|l|l|}
\hline $\begin{array}{l}\text { Diplomas and advanced } \\
\text { diplomas }\end{array}$ & $\begin{array}{l}\text { Vocational education } \\
\text { and training }\end{array}$ & Higher education \\
\hline Student load & 104,556 efts & 6,391 eftsu \\
\hline Proportion of all student load & $19.9 \%$ & $1.1 \%$ \\
\hline
\end{tabular}

Sources: National Centre for Vocational Education Research (2001) Australian vocational education and training statistics 2001, table 18; Department of Education, Science and Training (2002a) Students 2001: Selected higher education statistics, table 46.

Some $94 \%$ of all diploma and advanced diploma student load is therefore currently enrolled in vocational education and training institutions, but the sector's domination of these qualifications is relatively recent. 


\section{THE SITE OF EARLIER STRUGGLES}

Australian vocational education and training has struggled for control of diplomas and advanced diplomas since the sector's foundation in the late $19^{\text {th }}$ century (Goozee, 2001:7). In 1939 subgraduate diplomas and certificates were 15\% of all university enrolments (DEET, 1993:5). In 1964 the Murray committee on the future of tertiary education in Australia recommended the establishment of the advanced education sector of higher education, whose highest and distinctive qualification was to be the diploma. Universities were enjoined to relinquish their diplomas and concentrate on higher level study and research training, which was to be their distinctive role (1964). By 1977 diplomas were only 3\% of university enrolments and were $44.6 \%$ of advanced education enrolments.

TABLE 3: ENROLMENTS IN DIPLOMA LEVEL COURSES AS A PROPORTION OF ALL ENROLMENTS IN TECHNICAL AND FURTHER EDUCATION, COLLEGES OF ADVANCED EDUCATION AND UNIVERSITIES, 1977

\begin{tabular}{|c|c|c|}
\hline $\begin{array}{c}\text { Vocational education } \\
\text { and training }\end{array}$ & Advanced education & Universities \\
\hline $0.7 \%$ & $44.6 \%$ & $3.0 \%$ \\
\hline
\end{tabular}

Source: Williams (1979:20) table 1.7. 
Advanced education's dominance of diploma level enrolments in 1977 was the result of its taking over diplomas from technical colleges (ACOTAFE, 1975: para 5.69; Goozee, 2001:21), which was given considerable impetus by the Commonwealth’s decision to fund all these courses fully if offered in advanced education. As the Technical and Further Education Commission observed at the time (1976: para 5.59), by shifting diploma level courses from vocational education and training institutes which were largely funded by the States and Territories to colleges of advanced education which were fully funded by the Commonwealth, the States and Territories were able to shift costs to the Commonwealth. However, the Commonwealth continued to fund some diploma level programs offered by vocational education and training institutes, and a decade later the Commonwealth Tertiary Education Commission noted that a number of institutes in NSW, Queensland and Victoria were offering diplomas (1986: para 6.113).

Sub baccalaureate diplomas and advanced diplomas are therefore located ambiguously within Australian tertiary education to buy a peace, however uneasy, in the sectoral contest over the qualifications. There isn't similar ambiguity in the location of sub baccalaureate qualifications in North America and the United Kingdom.

\section{US AND UK COMPARISONS: SUB BACCALAUREATE TERTIARY QUALIFICATIONS}

In North America - most Canadian provinces and all US states - the sub baccalaureate tertiary qualification is the 2-year associate degree in arts or sciences. With a few exceptions they are offered only by non baccalaureate-granting tertiary education institutions, most 
commonly known as 2-year or community colleges. Students who complete an associate degree with an acceptable grade point average can transfer to a 4-year degree at a baccalaureate-granting university or college with credit for their associate degree. In most North American jurisdictions there are strong transfer arrangements between the associate degrees offered by 2-year colleges and the baccalaureates offered by 4-year colleges and higher institutions, and these transfer arrangements are required by law ('mandated') by the more closely coordinated states such as California, Colorado and Texas. Associate degrees are therefore understood to be higher education qualifications - known generically as shortcycle higher education - and in almost all jurisdictions 2-year colleges are categorised as a segment of higher education which also offers 'terminal' or vocational qualifications and general post compulsory education, for which the closest Australian analogy is adult education.

TABLE 4: QUALIFICATIONS BY TERTIARY EDUCATION SEGMENT, NORTH AMERICA

\begin{tabular}{|l|l|}
\hline Segment/qualification & Institutional type \\
\hline Higher education & \\
\hline Doctorate & Research university \\
\hline Masters & Comprehensive and \\
& research universities \\
Baccalaureate & comprehensive and \\
& research universities \\
\hline Associate degree & Community college \\
\hline
\end{tabular}




\begin{tabular}{|l|l|}
\hline $\begin{array}{l}\text { Vocational and general } \\
\text { education }\end{array}$ & \\
\hline Diploma & Community college \\
\hline Certificate & Community college \\
\hline
\end{tabular}

The sectoral distinctions in the United Kingdom are more familiar to an Australian observer, but interestingly the unequivocally higher education qualifications of the ordinary baccalaureate and foundation degree are offered by colleges of further education under licence or 'franchise' to a collaborating university or consortium of institutions as well as by universities in their own right (HEFCE, 2001b:4). Furthermore, following the adoption of the recommendation of the Dearing Committee, all higher education courses offered by colleges of further education in England are now funded by the Higher Education Funding Council for England. This covers all first degree, postgraduate, higher national diploma and certificate, diploma of higher education and certificate of education courses offered by colleges of further education (HEFCE, 2001a).

TABLE 5: QUALIFICATIONS BY TERTIARY EDUCATION SECTOR, UK

\begin{tabular}{|l|l|}
\hline Level/qualification & Institutional type \\
\hline Higher education & \\
\hline Doctorate & University \\
\hline Masters degree, & \\
postgraduate certificate, & University \\
\hline
\end{tabular}




\begin{tabular}{|l|l|}
\hline Honours degree, & \\
graduate certificate, & University \\
\hline foundation degree, & \\
higher national diploma & University and \\
\hline Higher national certificate & College of further education \\
\hline Further education & \\
\hline Various vocational & College of further education \\
certificates and diplomas & \\
\hline
\end{tabular}

The proportions differ in different provinces and states, but in North America associate degrees typically comprise from $10 \%$ to $30 \%$ of total higher education load. Some $11 \%$ of higher education load in England and 27\% of higher education load in Scotland is taken in colleges of further education (Parry \& Thompson, 2002). If diplomas and advanced diplomas were considered part of higher education in Australia, 15\% of higher education load would be taken in vocational education and training institutions.

TABLE 6: $\quad$ ENROLMENT IN SUB BACCALAUREATE QUALIFICATIONS AS A PROPORTION OF ALL HIGHER EDUCATION ENROLMENTS, SELECTED JURISDICTIONS

\begin{tabular}{|l|c|}
\hline Jurisdiction & $\mathbf{\%}$ \\
\hline Australia & $15 \%$ \\
\hline Canada & $10-30 \%$ \\
\hline
\end{tabular}




\begin{tabular}{|l|c|}
\hline England & $11 \%$ \\
\hline Scotland & $27 \%$ \\
\hline USA & $10-30 \%$ \\
\hline
\end{tabular}

\section{SECTORAL DIVIDE}

Australia's exclusion of vocational education and training from higher education is consistent with its almost complete organisational separation of the sectors. Responsibility for financing and coordinating vocational education and training is mostly with State and Territory governments, students pay tuition fees up front and the curriculum framework is set by training packages. Conversely, the Commonwealth has primary responsibility for financing and coordinating higher education (exclusive of diplomas and advanced diplomas taken in vet institutions), fees are mostly collected through the higher education contribution scheme and higher education's curriculum is based largely on content.

The organisational division between the sectors is less distinct in the other jurisdictions we are considering. While tuition fees for courses in non baccalaureate granting institutions are lower than in baccalaureate granting institutions, they are set within the same financing framework. This is partly because the sectors are now the responsibility of the same level of government in these jurisdictions. The non baccalaureate granting institutions have been brought within the same financing framework since US state governments gradually took over more responsibility for financing community colleges from local government districts from the 1980s and since the English government took over responsibility for financing colleges of 
further education from local government in 1992. Greatest variability remains in curriculum frameworks.

TABLE 7: SECTORAL DIVIDE IN AUSTRALIA AND SELECTED OVERSEAS JURISDICTIONS

\begin{tabular}{|c|c|c|}
\hline $\begin{array}{l}\text { Jurisdiction/ } \\
\text { administration }\end{array}$ & $\begin{array}{l}\text { Vocational education and } \\
\text { training }\end{array}$ & Higher education \\
\hline \multicolumn{3}{|l|}{ AUSTRALIA } \\
\hline Financing & States & Commonwealth \\
\hline Fees & Up front & HECS \\
\hline Curriculum & Training packages & Content \\
\hline \multicolumn{3}{|l|}{ CALIFORNIA } \\
\hline Financing & State Government & State Government \\
\hline Fees & Up front and loans & Up front and loans \\
\hline Curriculum & Mandated core & Mandated core at junior level \\
\hline \multicolumn{3}{|l|}{ CANADA } \\
\hline Financing & Provinces & Provinces \\
\hline Fees & Up front and loans & Up front and loans \\
\hline Curriculum & $\begin{array}{l}\text { Mandated in some provinces; } \\
\text { unregulated in others }\end{array}$ & $\begin{array}{l}\text { Mandated in some provinces; } \\
\text { unregulated in others }\end{array}$ \\
\hline \multicolumn{3}{|l|}{ ENGLAND } \\
\hline Financing & National & National \\
\hline Fees & Up front and loans & Up front and loans \\
\hline Curriculum & National vocational qualifications & Content \\
\hline
\end{tabular}


While the overlap of the Australian sectors at diploma and advanced diploma levels is not very large, the combination of overlap of qualification levels but almost complete separation of the sectors in almost all other characteristics generates a host of anomalies and inconsistencies. As the minister's overview paper for the Commonwealth's Crossroads review of higher education in 2002 observes, students pay different fees under different arrangements and with different levels of subsidy by different levels of government depending on whether they are taking the program in a vet or higher education institution

(Nelson, 2002, para 81). This may have some rationale were courses substantially different in each sector, but they are described almost identically by the Australian Qualifications Framework (2002), and there is considerable overlap between the sectors. The equivocal treatment of diplomas and advanced diplomas also causes difficulties for any Australian government that seeks to develop an integrated series of offerings between the sectors, as the Commonwealth argued in its issues paper Varieties of learning: the interface between higher education and vocational education and training (DEST, 2002b) relying on the work of Doughney (now Wheelahan) (2000).

\section{DISCUSSION: OPTIONS}

I consider five possible responses to the equivocal treatment of diplomas and advanced diplomas in Australian tertiary education. 


\section{Complete separation}

One way of removing the anomalies in the sectors' treatment of diplomas and advanced diplomas would be to remove the overlap in the sectors' responsibilities for the qualifications. This is rarely if ever done in Anglophone jurisdictions. But it has been achieved in bilingual Quebec, which neatly places its general and vocational colleges (collège d'enseignement général et professionnel) distinctively between secondary and higher education, since it is not possible to proceed from school to university without first completing the CEGEP's diploma of collegial studies (diplôme d'études collégiales) which normally takes 2 years full time after completing the secondary school diploma (Quebec, 2001).

TABLE 8: STANDARD PROGRESSION THROUGH QUEBEC’S EDUCATIONAL LEVELS

\begin{tabular}{|l|l|}
\hline Qualification & Institution \\
\hline Doctorate & University \\
\hline Masters & University \\
\hline Baccalaureate & University \\
\hline Diploma of collegial studies & General and vocational college \\
\hline Secondary school diploma & Secondary school \\
\hline
\end{tabular}

\section{Complete integration}

Another way of removing the inconsistencies at diploma and advanced diploma levels would be to harmonise the financing, coordination and other arrangements for vocational education 
and training and higher education. This would require both a restructuring of federal responsibilities for tertiary education comparable to the Commonwealth's assumption of full responsibility for financing the advanced education and university education sectors in 1974, and at the same time a recasting of the sectors which would be more extensive than the abolition of the higher education binary divide in 1988. Such an undertaking would be too ambitious to attempt in one step, even were the sectoral divide such a major problem as to require fundamental reform, and even were it the highest priority in Australian tertiary education.

\section{Intermediate sector: higher vocational education}

Another option would be to change diplomas and advanced diplomas from a site of duplication, overlap and competition between sectors and governments to a site of shared qualifications, responsibility and financing between the sectors and levels of government. This could be done by reconceptualising the qualifications as neither specifically vocational education and training nor specifically higher education, but as a new level of higher vocational education shared by both sectors. The new level could have curriculum, financing, fee and administrative arrangements which acted as a bridge to ease transition between the sectors.

\section{Decouple programmatic and institutional designations of the sectors}

A fourth option would be to follow North America and the UK in designating diplomas and advanced diplomas as short-cycle higher education, but leave them as the main responsibility of the non baccalaureate granting institutions, vocational education and training institutions in 
Australia. This would require Australia to decouple the institutional and programmatic designations of the sectors (Moodie 2002), but the Australian intersection of the programmatic and institutional designations of the sectors is relatively recent. Thus, less than 15 years ago Stevenson was still able to argue that 'since higher education is usually defined to include associate diploma and diploma courses, such a definition is not exclusive of the courses presently offered in tafe, the types of courses historically offered by tafe, or the courses which the community will continue to demand from tafe in the future' (1988:132).

This option would also require vocational education and training to manage higher education's student fees and financing arrangements for short-cycle higher education, but this is not as radical a change from vet's current arrangements as may at first seem. Australian vet already manages multiple student fee and financing arrangements: for programs sponsored by employers, for apprenticeships financed through so-called 'user choice', for students financed through labour market programs, for international students, for domestic fee-paying students, as well as for students funded through the State or Territory government's main student fee and financing arrangements.

\section{Nothing}

Finally, government could do nothing, or more likely, continue fiddling at the margins. This would be a sensible option notwithstanding the Commonwealth's attempt to problematise the relations between the sectors in its Crossroads review of higher education in 2002. There is no good measure of the extent of transfer between the sectors, but it is reasonable to infer that it is from the $7 \%$ of students commencing bachelor courses who are admitted on the basis of a TAFE qualification to the $14 \%$ of commencing bachelor students who have an advanced 
diploma, diploma or other TAFE qualification upon entry (DEST, 2002a). Even were transfers towards the top of that range, the volume of boundary problems would be small, or at least readily manageable within current arrangements. While duplication is untidy and appears inefficient, the sectors' duplication of diplomas and advanced diplomas is well within acceptable or at least tolerable bounds.

\section{CONCLUSION: SHORT-CYCLE HIGHER EDUCATION}

The current almost complete separation of Australian vocational education and training and higher education institutions, programs, financing and reporting arrangements, student fee arrangements, curriculum, accreditation and industrial representation (Moodie, 2002) is inhibiting sensible tertiary education policy. While each of these differences individually is not so great and can be worked around, in aggregate they entrench a separation of the sectors which may partly protect vocational education and training from higher education's periodic encroachment, but they also limit vet institutions’ role.

I prefer to follow the North American and United Kingdom examples and decouple the institutional and programmatic constructions of identity to designate vet's diplomas and advanced diplomas unequivocally as short-cycle higher education. This gives vet institutions a broader role, it would greatly improve access to higher education for people distant from a comprehensive higher education campus and it has the potential to improve access to senior higher education institutions. 


\section{ACKNOWLEDGEMENT}

An earlier version of this paper was presented at the $11^{\text {th }}$ national vet research conference in Brisbane on 12 July 2002. I thank Professor Chris Selby-Smith for his kindly critical comments then.

\section{REFERENCES}

Australian Committee on Technical and Further Education (ACOTAFE) 1975, TAFE in Australia: second report on needs in technical and further education, Australian Government Publishing Service, Canberra.

Australian Qualifications Framework advisory board to MCEETYA 2002, Australian qualifications framework: implementation handbook, www.aqf.edu.au.

Commonwealth Tertiary Education Commission 1986, Review of TAFE funding, Australian Government Publishing Service, Canberra.

Department of Education, Science and Training (DEST) 2002a, Students 2001: Selected higher education statistics, tables 15, 16 and 46, http://www.detya.gov.au/highered/statistics/students/01/tables.htm 
Department of Education, Science and Training (DEST) 2002b, Varieties of learning: the interface between higher education and vocational education and training, www.dest.gov.au/crossroads.

Department of Employment, Education and Training (DEET) 1993, National report on Australia’s higher education sector ('the blue book'), Australian Government Publishing Service, Canberra.

Doughney (now Wheelahan), L 2000, Bridging the divide: developing the institutional structures that most effectively deliver cross-sectoral education and training, NCVER, Adelaide, http://www.ncver.edu.au.

Goozee, G 2001, The development of TAFE in Australia, NCVER, Adelaide, http://www.ncver.edu.au.

Higher Education Funding Council for England (HEFCE) 2001a, Trends in higher education in further education colleges, http://www.hefce.ac.uk/Learning/FEFund/trends/FEtrends.doc

Higher Education Funding Council for England (HEFCE) 2001b, Higher education in the United Kingdom, http://www.hefce.ac.uk/pubs/hefce/2001/01_56.pdf

Martin L H (chair) Australian Universities Commission, Committee on the Future of Tertiary Education in Australia 1964, Report, Government Printer, Canberra. 
Moodie, G F 2002, 'On the level: two constructions of vet's identity’, paper presented to the $10^{\text {th }}$ annual international conference on post-compulsory education and training, Griffith University, Gold Coast.

National Centre for Vocational Education Research (NCVER) 2001, Australian vocational education and training statistics 2001, table 18 Annual hours by qualification by field of study and sex, http://www.ncver.edu.au/statistics/vet/ann01/id01/intnat01.pdf

Nelson, Brendan 2002, Higher education at the crossroads: an overview paper, www.dest.gov.au/crossroads.

Parry, Gareth \& Thompson, Anne 2002, Closer by degrees: the past, present and future of higher education in further education colleges, Learning and Skills Development Agency, www.LSDA.org.uk.

Quality Assurance Agency for Higher Education 2001, The framework for higher education qualifications in England, Wales and Northern Ireland, http://www.qaa.ac.uk/crntwork/nqf/ewni2001/ewni2001_textonly.htm

Quebec Ministere de l'education 2001, Education in Quebec http://www.meq.gouv.qc.ca/rens/brochu/anglais/m_educaqc.htm

Stevenson, J 1988 'Dismantling the barricades: the interface between tafe and higher education' in TAFE at the crossroads: relationships with government, secondary and 
higher education, ed Candy, P C, Department of Administrative and Higher Education Studies, University of New England, Armidale.

Technical and Further Education Commission 1976, Report for the triennium 1977-1979, Australian Government Publishing Service, Canberra.

Williams, B R (chair) 1979 Education, training and employment, report of the committee of inquiry into education and training, Australian Government Publishing Service, Canberra. 